to the task of many editors of scientific journals, among which are the increasing number of papers selected and recommended for publication, in this case by an independent advisory board; the endeavour to contain this material within the bounds of the Magazine itself; and the consequent increasing lapse of time between the receipt of a manuscript and its appearance in print. Another factor in the situation is that latterly discussions of papers published have tended to be crowded out by the pressure of new contributions awaiting publication. A further innovation in this Magazine is described in the editorial comment: "This ever-increasing volume of published material presents the research worker and the librarian with problems in their turn. However, to offset the extra contribution which the Magazine will be making in future, it has been decided to include abstracts of the articles appearing in the Magazine, and this issue contains the first of these abstracts. The abstracts themselves are printed on a separate sheet so that their removal from the Magazine will not spoil its appearance in any way". 'The abstracts are the authors' own summaries; they are printed on pale-green card, each comfortably contained within a delineated area of $6 \times 4$ in., which can easily be cut out for card-indexing. This is a feature which could well be copied in other technical journals to facilitate quick reference. The editorial advisory board, equally the Editor himself, are to be congratulated on the determination and pursuit of a policy which ean only serve to enhance the prestige and long-proved value of this excellent publication.

\section{The Museums Journal}

Vol. 64 , No. 1, of The Museums Journal is devoted to the scientific aspects of the work of museums and art galleries. In this field, science has two functions- the conservation of objects in the museum and the preservation of the apparatus used by the early scientists. Dr. A. E. Werner doals with some of the endless variety of materials now available for conservation work, and $\mathrm{Mr}$. G. Thomson with the chemical and physical aspects of the changes which occur in various objects. Mr. S. Slabczynski describes a moderately sized laboratory for the restoration of paintings, and Mr. F. Greenaway gives an admirable illustrated description of the new Chemistry Gallery at the Science Museum, Kensington. Mr. N. W. Bertenshaw similarly describes the Industrial Museum at Birmingham and touches on the basic principles involved in the establishment and maintenance of such museums, while Mr. B. J. Ford details a new technique for mounting museum specimens which consists of sealing a jar by means of a solution of polystyrene in xylene. The annual report of the Council of the Museums Association for 1963-64 concludes an especially interesting number.

\section{Man as a Subject for Science}

THe sixth Auguste Comte Memorial Lecture was delivered by Prof. A. J. Ayer at the London Sehool of Economics and Political Science on February 7, 1964, under the title "Man as a Subject for Science" (Pp. 26. London: The Athlone Press, University of London. Distributed by Constable and Co., Ltd., 1964. 5s. net). Pointing out that the social sciences can only mustor a comparntively small stock of generally accredited and well-tested theories, Prof. Ayer suggests that their relatively poor stock of generalizations may be due to something inherent in the material with which social scientists have to work. He recognizes that this idea must be received with caution and that the issue of determinism must be decided. The important question is whether human behaviour is, or is not, entirely subject to law. In discussing this, Prof. Ayer does not accept as necessarily true the common belief among philosophers that motives are not causes and suggests that causal relations should be regarded as holding between facts rather than events - where 'fact' is understood in the wide sense in which true propositions of any form can be taken as expressing facts. He does not, however, think that the issue of determinism should be interpreted as an a priori question. The strength of the determinists lies in the fact that there seems to be no reason why the reign of law should break down at this point, though this argument seemed more convincing in the age of classical physics than it does to-day; that of the indeterminists lies in the fact that the specific theories which alone could indicate or give any substance to their opponents' case have not yet been more than sketched. Until such theories are properly elaborated and tested, Prof. Ayer thinks that there is little more that can usefully be said about this topic. As to whether the denial of determinism is implied in our usual ascriptions of moral and legal responsibility, in so far as this is a question of what people actually believe, Prof. Ayer is now inclined to believe that the antithesis between the claims of free will and determinism is not illusory but that our ordinary ideas of freedom and responsibility are very muddleheaded although firmly held. It would not be at all easy to estimate the social consequences of discarding them.

\section{Man, the Social Animal}

THE first part of K. W. Monsarrat's On Human Wisdom is concerned with man's innate ideas regarding the nature of and the structure of what he names "I myself" and "the world", including his attempts to give subjective and objective accounts of both and the value of the relative truths given to man by his validity judgments (Pp. 24. Liverpool: Henry Young and Son, Ltd., 1964. $6 s$.). The second part is concerned with man in his social relations, discussing the dependence of the stability of social groups on the quality and degree of aid which the individuals composing them have given to each other and emphasizing that, on the national level, the attainment and retention of prosperity depend on the Government being concerned for the welfare of all its members and seeking agreements on the rewards due for the various types of work they perform. He sees the pattern of Government noeded as provided in microcosm by the physiological account of the function performed by the nervous sub-system in organizing the dynamic relations between the organs comprising the individual. Reviewing briefly Britain's social history and the functioning of the Coalition Government in the Second World War, Mr. Monsarrat postulates for the future Government of Britain a cessation of party conflict within Parliament; a Parliament of men whose overriding interest is the cultivation of mutual aid and friendship in all home affairs and who will eall on the whole people to unite in a war-effort against war and disease in any nation, and undeterred by any alliance from including in its offers of aid and friendship the U.S.S.R., China or any other nation. Such a Parliament could plan a more promising effort to prevent global war than sending delegates to a disarmament conference. It would also implement a fair-shares-ofwealth policy, firmly based on the value of contributions to the nation's well-being and on the education and training needed for different types of work.

\section{Leukopoiesis in Health and Disease}

Article 2 of Volume 113 of the Annals of the New York Academy of Sciences is entitled "Leukopoiesis in Health and Disease" (By Howard R. Bierman and 124 other authors. Pp. 511-1092. New York: New York Academy of Sciences, 1964. 8 dollars). The forty original papers in this volume (one of the largest in the series) were presented at a conference in May 1963. The origin and formation of the white cells of the blood have been the subject of increasingly concentrated research in recent years, and this collection gives a cross-section of present trends. Certain widely influential notions have strongly influenced attitudes and methods in this field; for example, fluctuations in the relative or absolute numbers of white blood 